\title{
Introduction
}

\section{Governing the Climate-Energy Nexus}

\author{
FARIBORZ ZELLI, KARIN BÄCKSTRAND, NAGHMEH NASIRITOUSI, \\ JAKOB SKOVGAARD, AND OSCAR WIDERBERG
}

Energy and climate change are fundamentally connected. In today's world energy production and use account for two-thirds of global greenhouse gas emissions (IEA 2018). To curb the climate crisis and to meet the goals set out in the Paris Agreement, we need to provide reliable and affordable energy to some 10 billion people. This much needed transition to low- or zero-carbon societies would have profound consequences for the world's energy systems (Lesage and Van de Graaf 2016).

Many steps have already been taken to bring this transition on its way, and they include an ever-increasing number of governance initiatives across borders. The success of this transition - and therewith the future quality of life on our planet depends on how effectively and legitimately these various governance efforts achieve their goals, and this without undermining each other too much. In short, coordinated policy responses to limit climate change and decarbonize energy systems worldwide need to go hand in hand.

Against the backdrop of this urgent link between global climate change governance and global energy governance, this volume puts the 'climate-energy nexus' at the forefront. Both governance structures making up this nexus are highly complex (Sovacool 2013; Goldthau et al. 2018). Efforts to tackle climate change have increased significantly over the past twenty and more years, and they have expanded far beyond the multilateral response under the United Nations Framework Convention on Climate Change (UNFCCC) (Vogler 2018). These efforts vary from minilateral, local, and transnational initiatives to private regulation, technology agreements, and market-based mechanisms (Hoffman 2011; Hjerpe and Nasiritousi 2015). Likewise, governance efforts to address energy demands on the international level are fragmented, and even lack a core multilateral institution similar to the role the UNFCCC plays within the institutional complex on climate change (Sovacool and Florini 2012; Wilson 2015; Van de Graaf and Colgan 2016; Sovacool and Van de Graaf 2018). 
This fragmented climate-energy nexus may imply severe challenges for both state and nonstate actors to effectively combat climate change and transition to fossil-free energy systems (Falkner 2014). There is limited knowledge to which degree the fragmentation translates into (in)coherence, and what kind of consequences the degree of coherence has on the effectiveness and legitimacy of governance efforts. Apart from the number of institutions a range of other dimensions are also at play, including the kinds of actors involved, interpretations of core norms and distribution of governance functions (see Chapter 2; Biermann et al. 2009; Eberlein et al. 2014). One important aspect that has been sidelined in the literature is that governance in the climate-energy nexus is rarely governance of the climate-energy nexus in its entirety: Governance in the nexus mainly targets subfields focusing on specific issues such as renewable energy, carbon pricing, or fossil fuel subsidies.

This book aims to address this research gap and identify connections between the plethora of institutions and actors that address climate change and energy challenges within and across specific governance subfields. First, it provides novel mappings of the institutional complex of the climate-energy nexus as a whole and of the respective complexes governing three major policy subfields within the nexus - renewable energy, fossil fuel subsidy reform, and carbon pricing. Second, and based on this mapping, the volume analyzes the degrees of institutional coherence for all three subfields and studies to what extent there have been deliberate management attempts targeting the interlinkages between institutions. Third and finally, the consequences of the multifaceted institutional complex in the climate-energy nexus are examined by asking how the institutional complexity affects perceptions of effectiveness and legitimacy across the selected subfields.

The next three sections explain the rationale and theoretical and empirical contributions of the edited volume and our motivation to select three specific policy subfields as case studies. The introduction concludes with an outline of the chapters, structured along the book's three parts on mapping, coherence and management, and legitimacy and effectiveness.

\subsection{Rationale behind This Book}

A defining feature of global environmental governance today is the patchwork of overlapping institutions with varying forms and functions that govern different aspects of environmental challenges (cf. Young 1996; Oberthür 2009; Zelli and van Asselt 2013; van Asselt and Zelli 2014; Heubaum and Biermann 2015; Pattberg and Widerberg 2015; Boas et al. 2016). A case in point is the intersection of global climate and energy governance. 
International, transnational and nonstate action to mitigate climate change has proliferated in number and scope in the lead-up to the Paris Agreement (Bulkeley et al. 2014; Jordan et al. 2015; Bäckstrand et al. 2017; van Asselt and Zelli 2018). For instance, the Non-State Actor Zone for Climate Action (NAZCA) online portal, ${ }^{1}$ maintained by the United Nations Framework Convention on Climate Change (UNFCCC) Secretariat, has identified more than seventy cooperative initiatives involving governments (of which more than twenty specifically target energy), in addition to thousands of nonstate and subnational climate actions.

At the same time, national sovereignty concerns have left multilateral cooperation on energy without a central or focal institution similar to the UNFCCC in climate governance (Karlsson-Vinkhuyzen 2010; Sovacool and Florini 2012; Barnsley and Ahn 2014; Wilson 2015; Van de Graaf and Colgan 2016; Sovacool and Van de Graaf 2018). As current energy systems are a major source of greenhouse gas emissions, transformation in the consumption and production of energy in major emitter states, across developing and developed countries, is a key in setting the world on a low-carbon path (Goldthau and Witte 2010; Cherp et al. 2011; Dubash and Florini 2011; Nasiritousi 2017; IEA 2018). Hence, the socioeconomic and biophysical interactions between climate and energy are very strong.

In this volume, three central issues at the intersection of climate and energy governance have been selected: renewable energy, fossil fuel subsidy reform, and carbon pricing. Comparing these three policy areas, it can be observed that they are characterized by multiple governance institutions and a patchwork of actors, rules, and decision-making processes (Van de Graaf and Colgan 2016; Sanderink et al. 2017). Renewable energy, to take one example, is discussed not only within the United Nations (UN), but also in technology partnerships and international organizations such as the International Renewable Energy Agency (IRENA), the Clean Energy Ministerial (CEM), the Climate Technology Initiative (CTI), Energy + , and in a number of private-public partnerships and private initiatives such as the Renewable Energy Policy Network for the 21st Century (REN21) (Widerberg and Pattberg 2015; Sanderink et al. 2017; Sovacool and Van de Graaf 2018). Many of these institutions have overlapping mandates and memberships among governments and nongovernmental actors, while exercising different governance functions (Keohane and Victor 2011; see also Biermann et al. 2009).

Institutional complexity in general as well as the relationship between climate and energy governance in particular are attracting growing interest among scholars (e.g. Bäckstrand 2008; Zelli 2011; Van de Graaf 2013; Widerberg and

\footnotetext{
${ }^{1}$ https:climateaction.unfccc.int/ (accessed 23 February 2018).
} 
Stenson 2013; van Asselt 2014; Falkner 2018; Goldthau et al. 2018). Their research has shown that the increasing number of partnerships in climate and energy governance has contributed to the fragmentation of the institutional landscape (Biermann 2009; Van de Graaf 2013; Zelli et al. 2013; Jordan et al. 2015). Terms such as 'regime complex' (Keohane and Victor 2011), 'polyarchy' (Ostrom 2010), 'fragmented governance architectures' (Biermann et al. 2009), and 'climate anarchy' (Dyer 2014) equally reflect this development in current global environmental governance. And significant research efforts have demonstrated that this complexity also marks the intersections between policy domains, for instance, between the global governance of climate change and other policy areas such as trade (e.g. Charnovitz 2003; van Asselt 2014), biodiversity (e.g. Jacquemont and Caparrós 2002), or development and security (e.g. Moncel and van Asselt 2012).

Beyond the institutional complexity literature, the book also contributes to discussions around various 'nexuses' in public policy objectives. Over the past fifteen years, the nexus concept has become a popular way to illustrate connectivity between various policy fields. The 'water-food-energy' nexus has been a particular focus of attention (e.g. Hoff 2011) but other combinations abound. The nexus concept has been used to connect just about any policy field, including, to name but a few, climate change, gender, health, poverty, education, and agriculture (e.g. Clancy et al. 2002; Iguchi et al. 2014). Thinking in terms of nexuses among policy fields - instead of individual policy fields - is expected to generate insight into trade-offs and synergies between various policy decisions, or, as the UN's Food and Agricultural Organization $(2014,4)$ puts it: a nexus approach 'forces us to think of the impacts a decision in one sector can have not only on that sector, but on others. Anticipating potential trade-offs and synergies, we can then design, appraise and prioritise response options that are viable across different sectors'. Policies to address climate change using forests as carbon sinks, for instance, may have impacts on biodiversity, agriculture, and water and they require decision makers to take an integrated approach toward sustainability challenges. For researchers studying a nexus, enhancing policy coherence is hence key to reap the benefits of potential synergies and mitigate negative effects across various policy goals (Munaretto and Witmer 2017).

The achievements of these different literatures on climate change, energy, complexity, and nexuses notwithstanding, there are several research questions that have not been comprehensively addressed so far. First, there are few attempts to analyze the nexus between climate change and energy by comparing the institutional complexes for specific subfields (e.g. Bazilian et al. 2011; Sovacool 2011; Bradshaw 2014; Falkner 2014, 2018; Van de Graaf and Colgan 2016). Second, while all studies share the starting assumption that institutional complexity matters, 
there are no systematic comparative analyses about how exactly it may affect the effectiveness or legitimacy of individual institutions or entire institutional complexes, or how certain actors may benefit or be disadvantaged in a complex governance architecture (Andresen and Hey 2005; Karlsson-Vinkhuyzen and McGee 2013; Bäckstrand et al. 2018; Sovacool and Van de Graaf 2018). Third, in empirical terms, the scholarship on institutional interactions has mostly provided insights into dyadic relationships between two international regimes or public institutions composed by national governments (Oberthür and Gehring 2006; Chambers 2008; Young et al. 2008; Gehring and Oberthür 2009; Oberthür and Stokke 2011), while placing less emphasis on broader governance interactions that also include hybrid, private, and informal institutions (Heubaum and Biermann 2015; Sanderink et al. 2017).

In summary, there is a gap in knowledge of the nature of the relationship between institutions governing the climate-energy nexus in a multilevel context as well as the implications of that institutional complexity. This book seeks to address these gaps.

\subsection{Objectives and Contribution: Analyzing the Climate-Energy Nexus}

The aim of this volume is to comprehensively map, critically analyze, and compare a wide range of interactions among intergovernmental and transnational institutions across three policy fields in the climate-energy nexus.

Conceptually, this book advances the research frontier in the scholarship on institutional complexity and fragmentation (Zelli and van Asselt 2013) by zooming in on governance interaction and policy integration between state and nonstate actors. The linkages between institutions are conceptualized along four evaluative themes and their respective dimensions: (1) coherence and (2) management of institutional complexes as well as their consequences for the (3) legitimacy and (4) effectiveness of institutions within institutional complexes.

Empirically, the contributions to this book break important new ground, as they provide novel findings on the institutional complexes that govern three central policy domains: renewable energy, fossil fuel subsidy reform, and carbon pricing.

Theoretically, the book explores how the position of a policy field in a nexus may influence the degree of complexity between institutions.

The following research questions guide this book:

Mapping: What is the institutional structure addressing the climate-energy nexus? Which types of institutions and actors are involved, which governance 
functions do they perform, and which specific policy field (e.g. renewable energy) do they address?

Coherence and Management: Are the relations between institutions in different subsets of the climate-energy nexus conflictive or synergistic? To what extent are there convergence, divergence or governance gaps with regard to overarching norms, governance functions, and membership? Are there deliberate attempts to address shortcomings of cross-institutional relations by certain actors?

Legitimacy and Effectiveness: What do the interactions between various institutions in global climate and energy governance mean for the legitimacy, legitimation, and effectiveness of individual institutions and the climateenergy nexus as whole?

We address these questions in three consecutive parts: In Part I, we introduce the conceptual and analytical framework and provide comprehensive mappings of the institutional structure of the climate-energy nexus as a whole. Part II provides indepth analyses on the coherence and management of three policy domains of the climate-energy nexus: those addressing renewable energy, the phasing out of fossil fuel subsidies, and carbon pricing. Part III presents comparative studies that examine whether, and in which ways, different types of institutions working in the same policy field are perceived as legitimate or effective.

Across these three parts, the analyses build on a mixed-methods approach, including content analysis, network analysis, surveys, and semi-structured interviews with key stakeholders and experts. Moreover, all three parts provide a multilevel governance perspective on the climate-energy nexus. While the book departs from an analysis of the global governance of the nexus, several chapters examine roles and perceptions at the domestic and sub-state levels. On the one hand, preferences of member states (such as China, USA, EU) and energy industry actors set the agenda for global institutions. On the other hand, governments and stakeholders are affected by the high level of institutional complexity of global climate and energy governance. Some actors are better equipped than others to navigate the complex institutional system and, likewise, their perceptions of the legitimacy and effectiveness of certain institutions may differ considerably.

\subsection{Three Case Studies: Renewable Energy, Fossil Fuel Subsidy Reform, and Carbon Pricing}

We selected three policy subfields within the climate-energy nexus based on three main criteria. The first of these is the urgency and importance of each subfield in decarbonizing energy systems and combating climate change. 
The subfield of renewable energy is key for a sustainable future, as the global uptake of renewable energy plays a central role in the decarbonization of global energy systems (Röhrkasten 2018). As Chapter 4 by Sanderink lays out in further detail, renewable energy is crucial for addressing three closely connected energy goals simultaneously: to provide energy security by satisfying increasing energy demand; to ensure worldwide energy access, with currently 1.1 billion people not having access to electricity; and to tackle negative environmental externalities associated with today's energy systems, with climate change being arguably the most important of these.

Fossil fuel subsidy reform (FFSR) covers the complex of institutions that seek to rationalize and phase out inefficient subsidies in the medium term (Chapter 5 by Verkuijl and van Asselt). Such subsidies potentially lock in an unsustainable fossil fuel infrastructure for years to come. According to estimates, more than a third of carbon emissions between 1980 and 2010 were driven by fossil fuel subsidies (Stefanski 2016), and phasing them out could at least reduce carbon emissions by 10 per cent (UNEP 2018).

The rationale of the subfield of carbon pricing is that climate change is best mitigated by giving emitters an incentive to reduce emissions through price signals, with the decision of how to reduce emissions best left to the market (Chapter 6 by Skovgaard and Canavan). With a few exceptions, emissions covered by carbon pricing arise from energy use (within industry, transportation and power generation), and carbon prices therefore help direct the choice of fuels away from emissions-intensive ones.

Second, as Chapters 4-6 demonstrate, these three policy subfields vary considerably in the number and mix of institutions that govern them at the international level. With this cross-case variation as a second selection criterion, the book provides an insightful comparison of the very different institutional complexes, their coherence and management, and the various consequences for legitimacy and effectiveness.

The renewable energy subfield is governed by a wide range of different institutions, including intergovernmental organizations alongside private institutions and multi-stakeholder partnerships. This notwithstanding, the subfield is still dominated by national policy-making as nation states continue to have sovereign control over the energy domain. By contrast, the carbon pricing subfield is predominantly governed on the international level and the respective institutional complex exhibits a medium number of public, private, and hybrid institutions. Membership in the few existing international FFSR institutions, finally, is heavily skewed toward public institutions, while the role of private and hybrid institutions is limited for this subfield.

A third and final case-selection criterion relates to the variation within the thematic structure in which a problem or policy field is embedded. In this 
volume, the climate-energy nexus constitutes this structure. In other words, we take into account the position of a policy subfield within the climate-energy nexus. Positioning is here understood as the degree to which the theme of a subfield is defined as a climate or energy problem, as well as the extent to which policy measures within the field (intentionally or not) influence carbon emissions and energy use.

The three selected policy fields indeed differ in their positioning within the climate-energy nexus. Carbon pricing is mainly related to climate change, since the notion of pricing carbon emissions is based on the definition of climate change as a policy problem. This said, while carbon pricing only aims to address climate mitigation, it mainly targets emissions from energy use (Métivier et al. 2018; Postic and Métivier 2019), and induces less energy consumption and a shift from high emission to lower emission energy sources. Fossil fuel subsidy reform is arguably as much a climate change policy problem as an energy issue. The subsidies as such target energy use, but fossil fuel subsidy reform is increasingly defined as a climate mitigation instrument (Terton et al. 2015; Jewell et al. 2018; Van de Graaf and Blondeel 2018). Finally, renewable energy is rooted in the energy domain, alhough one of the main purposes of promoting renewable energy is reducing carbon emissions.

The positioning of the policy fields within the climate-energy nexus matters, inter alia, due to the different governance architectures addressing climate change and energy. Whereas climate change is governed by a fragmented system with one central institution, the UNFCCC (Biermann et al. 2009), energy is governed by a fragmented and decentralized governance architecture without one central institution (Van de Graaf and Colgan 2016). Consequently, renewable energy operates further from the gravitational influence of the UNFCCC than fossil fuel subsidy reform and especially carbon pricing.

In the conclusions, this problem-structural argument and selection criterion will be revisited. We will discuss to what extent the different nature of the three problems is mirrored in different institutional architectures and different consequences for legitimacy and effectiveness.

Having introduced our rationale behind selecting the three policy subfields, we like to make one important qualification: the delineation of a governance problem or policy field has an unavoidable element of construction to it, since it depends on how the observers define the overarching norm, goal, or essence of the field in question. In formulating the core norms for each of the three subfields (see Chapters 4-6 for elaborate definitions of the respective norms), the authors therefore made necessary subjective assessments of what counts as a subfield within the climate-energy nexus. 


\subsection{Structure of the Book}

\subsubsection{Mapping the Climate-Energy Nexus}

Part I consists of two chapters that provide analytical guidance and overarching empirical mappings. Chapter 2, by Zelli, Nasiritousi, Bäckstrand, Pattberg, Sanderink, Skovgaard, van Asselt, and Widerberg, introduces the overarching analytical framework for this book. The chapter first establishes our understanding of key terms such as institutions, institutional complex, nexus, and global governance. In a second step, it distinguishes three analytical levels for investigating institutional complexity: the macro level, which captures the overarching institutional fragmentation for a given field or domain of global governance; the meso level, which zooms into specific subfields of such a domain and the institutional complexes thereof; and the micro level, which exhibits interlinkages among two individual institutions on specific questions.

Chapter 2 then establishes the four evaluative themes that are employed in Parts II and III: coherence, management, legitimacy, and effectiveness. For each of these themes a series of dimensions is introduced to guide the examination of the meso and micro levels of a policy field. Coherence among institutions, for instance, is conceptualized in terms of: adherence to and interpretation of an overarching core norm for the policy field, coverage and distribution of memberships (private, public, hybrid), coverage and distribution of governance functions (standards and commitments, operational activities, information and networking, financing), and mechanisms underlying cross-institutional relations (cognitive, normative, behavioural). Legitimacy, to give another example, is to be assessed along nine dimensions, among them expertise, transparency, accountability, procedural fairness and distributive fairness. Altogether, the four themes and their dimensions make up a novel framework for an in-depth analysis of a governance nexus, such as the one on energy and climate change. They help us examine a variety of important questions in a comparative research design, combining a high level of ambition with feasibility and novelty.

Chapter 3, by Sanderink, Pattberg, and Widerberg, provides an innovative institutional mapping of the climate-energy nexus as a whole by applying the coherence dimensions of the analytical framework. The mapping presents a newly built database and novel methodology to identify intergovernmental or transnational institutions with a direct objective to steer society in various directions in terms of energy and climate change. It uses a 'governance triangle' developed by Abbott and Snidal (2009) to categorize the various institutions depending on their constitutive members and other institutional characteristics such as governance functions and thematic focus. The results show nearly 110 institutions in the climate-energy nexus, comprising more than 13,000 members, including public, 
private, and civil society actors, of which more than 8,000 are cities. The chapter also offers a network analysis of the nexus, demonstrating the tight web of institutions connected by primarily public actors and the centrality of the European Union and a few countries, including the United States and the United Kingdom, within that web.

Chapter 3 also provides the empirical basis for the further analyses in the subsequent chapters: it zooms in on the institutional constellations of the three subfields of renewable energy, fossil fuel subsidy reform, and carbon pricing. Similar to the analysis of the nexus as a whole, the chapter highlights for each of these subfields the constitutive characteristics of the respective institutions and the governance functions they perform. The results are first insights into the differences, commonalities, and varying degrees of complexity across the three institutional complexes. In sum, the chapter provides the first step in creating a knowledge base to guide actors that aim to navigate the institutionally complex global climate and energy governance system.

\subsubsection{Coherence and Management in the Climate-Energy Nexus}

Part II of the book zooms in on the three subfields and applies the analytical framework's dimensions of coherence and management.

Chapter 4 by Sanderink examines coherence and management for the renewable energy subfield. After introducing the central role of renewables in the global energy transition, the chapter presents the wide array of forty-six public, private, and public-private institutions that currently govern the subfield. These include intergovernmental organizations such as the International Energy Agency (IEA) and IRENA, but also private initiatives and multi-stakeholder partnerships such as RE100 and REN21. These various institutions not only differ in terms of their institutional characteristics but also with regard to the energy sources and technologies they cover, the governance functions they perform, and the energy-related objectives they prioritize.

Following this analysis of the meso level, the chapter concentrates on three multi-stakeholder partnerships to determine micro-level coherence and identify inter-institutional management attempts: the Renewable Energy and Energy Efficiency Partnership (REEEP), REN21, and Sustainable Energy for All (SEforALL). This assessment is based on a thorough analysis of the institutional characteristics of the selected partnerships, a qualitative review of their official documents, and semi-structured interviews with the experts involved. The result is a detailed overview of the institutional overlaps and differences, various interaction mechanisms, and several management attempts between and beyond these institutions. Based thereon, Chapter 4 concludes to what extent renewable energy subfield can 
be characterized in terms of categories such as division of labour, synergy, coexistence, or competition.

In Chapter 5, Verkuijl and van Asselt examine coherence and management across the institutional complex of fossil fuel subsidy reform. By reducing carbon emissions and enabling the redirection of public funds into areas such as health, education, and renewable energy, the reform of subsidies for the production and consumption of fossil fuels can support the goals of the Paris Agreement as well as a range of broader sustainable development objectives. However, although the benefits of their reform have been widely acknowledged, fossil fuel subsidies persist in both developed and developing economies. Most scholars addressing this puzzle have done so primarily through the lens of domestic politics.

Chapter 5, by contrast, considers how various international institutions are approaching FFSR governance. The authors briefly introduce the rationale for FFSR, before analyzing the coherence of the institutional complex at the meso level. This includes the possible emergence of a core norm of FFSR, membership distribution, and the governance functions carried out by the various international institutions active in this area. To further evaluate the degree of coherence in this field, the chapter zooms in on the micro level. Concretely, the authors examine a subset of three international clubs whose FFSR activities are among the most prominent globally: the Group of 20 (G20), the Asia-Pacific Economic Cooperation (APEC), and the Friends of Fossil Fuel Subsidy Reform. They first introduce the FFSR activities undertaken by each of these three institutions, and then, drawing on interviews, consider the interlinkages between these activities, as well as efforts to manage them. The chapter concludes by considering implications of the findings for the future management of FFSR governance and the complexity thereof.

Chapter 6 by Skovgaard and Canavan examines the third case study of the complex of institutions promoting carbon pricing. Carbon pricing - in the shape of carbon taxes, emissions trading, and offsets - places a price on the emission of carbon and mainly targets emissions from energy consumption. Advocates of carbon pricing have promoted it as the solution, or at least as one of the key tools to combat climate change. Even if one does not subscribe to these claims, carbon pricing can provide significant emissions reductions as well as fiscal revenue. Previous studies of carbon pricing have mainly focused on economic aspects and on single cases of pricing efforts at national, provincial, and European Union levels. This chapter contributes to the literature by focusing on the neglected issue of what the governance of carbon pricing looks like on the international level. It does so by mapping the thirteen international institutions that constitute the carbonpricing subfield and by assessing the degree of cross-institutional coherence, i.e. 
identifying to what extent the institutions can be organized into specific clusters. The examined carbon pricing institutions are public, private, and hybrid in nature. They overlap in terms of membership, geographical scope, and governance functions and to some degree differ in their interpretation of the core norm of carbon pricing.

Moreover, Chapter 6 focuses on the interlinkages between, on the one hand, the UNFCCC and, on the other hand, three World Bank-based institutions: the Carbon Pricing Leadership Coalition, the Networked Carbon Markets, and the Partnership for Market Readiness. These interlinkages, the (cognitive, normative, or behavioural) mechanisms through which they take place, and the attempts to manage them are studied through key informant interviews and official documents. The chapter finally discusses to which extent the subfield of carbon pricing can be characterized in terms of synergy, division of labour, coexistence, coordination, conflict, or competition.

\subsubsection{Legitimacy and Effectiveness in the Climate-Energy Nexus}

Part III examines the consequences of the degree of institutional complexity that we identified in the previous part. Two chapters will examine how the legitimacy and effectiveness of institutions can be assessed against the backdrop of the normative, functional, and membership-related coherence of the subfields in which these institutions are embedded.

Chapter 7 applies the evaluative theme of legitimacy that we introduced in Chapter 2. Nasiritousi and Verhaegen examine how stakeholders assess a set of institutions within the renewable energy subfield along nine dimensions of legitimacy. Given the proliferation of institutions with overlapping mandates, institutions rely on favourable legitimacy perceptions by a range of stakeholders in order to attract members and resources. By focusing on those aspects of legitimacy that the institutions themselves can affect, the chapter examines how assessments of institutional qualities differ between a diverse set of stakeholder groups.

Specifically, the chapter analyzes results from an expert survey among energy and climate stakeholders, including governmental and nongovernmental stakeholders from different world regions. Respondents were asked to assess five climate and energy governance institutions that exhibit different but overlapping mandates and membership: the IEA, CEM, IRENA, REN21, and UNFCCC. Through this systematic and comparative mapping of stakeholders' legitimacy assessments, the chapter offers novel insights into legitimacy under institutional complexity and concludes by discussing implications for institutions' legitimation strategies. 
In Chapter 8, Nasiritousi, Sanderink, Skovgaard, van Asselt, Verkuijl, and Widerberg ask: How do institutional linkages affect the performance and the effectiveness of individual institutions and how can performance and effectiveness be strengthened in the institutionally complex nexus of global climate and energy governance? The chapter addresses these questions for the three subfields studied in this book: renewable energy, fossil fuel subsidy reform, and carbon markets. It starts off with discussing the concept of effectiveness and highlighting the challenges to analyzing the effectiveness of institutions, especially when they have overlapping mandates and are interlinked. In order to respond to these challenges, our research relies on a two-track approach, integrating assessments by researchers and interviews with key stakeholders.

By examining the outputs, outcomes, and impacts of the three subfields, the chapter shows both the advantages and the disadvantages of institutional complexity in the climate-energy nexus for achieving effectiveness. Through its crosscutting perspective, the study identifies a set of management options and discusses opportunities and barriers to reform the nexus. It concludes by outlining implications for overcoming some of the downsides of institutional complexity.

The conclusions of this book in Chapter 9 provide a critical review of the conceptual, empirical, and theoretical contributions in this volume. First, we summarize the major novelties and findings, systematically contrasting the empirical results for coherence, management, legitimacy, and effectiveness across the subfields of the climate-energy nexus. Second, the chapter explores to which extent the results across the institutional complexes for renewable energy, FFSR, and carbon pricing can be explained or understood by the problem-structural approach we introduced previously - i.e. by the nature of the problem to be regulated and its position within the climate-energy nexus - or by alternative approaches. Third, we discuss potential policy recommendations that could be derived from the findings. Finally, the chapter suggests a future research agenda on the governance of the climate-energy nexus.

\subsection{References}

Abbott, K. W. and Snidal, D. 2009. The Governance Triangle: Regulatory Standards Institutions and the Shadow of the State. In The Politics of Global Regulation, edited by W. Mattli and N. Woods. Princeton: Princeton University Press.

Andresen, S. and Hey, E. 2005. The Effectiveness and Legitimacy of International Environmental Institutions. International Environmental Agreements: Politics, Law and Economics 5(3), 211-226.

Bäckstrand, K. 2008. Accountability of Networked Climate Governance: The Rise of Transnational Climate Partnerships. Global Environmental Politics 8(3), 74-102. 
Bäckstrand, K., Kuyper, J. W., Linnér, B.-O., and Lövbrand, E. 2017. Non-State Actors in Global Climate Governance: From Copenhagen to Paris and Beyond. Environmental Politics 26(4), 561-579.

Bäckstrand, K., Zelli, F., and Schleifer, P. 2018. Legitimacy and Accountability in Polycentric Climate. In Governance Governing Climate Change: Polycentricity in Action? edited by A. Jordan, D. Huitema, H. van Asselt, and J. Foster. Cambridge: Cambridge University Press.

Barnsley, I. and Ahn, S.-J. 2014. Mapping Multilateral Collaboration on Low-Carbon Energy Technologies. Paris: International Energy Agency.

Bazilian, M., Hobbs, B. F., Blyth, W., MacGill, I., and Howells, M. 2011. Interactions between Energy Security and Climate Change: A Focus on Developing Countries. Energy Policy 39(6), 3750-3756.

Biermann, F., Pattberg, P., van Asselt, H., and Zelli, F. 2009. The Fragmentation of Global Governance Architectures: A Framework for Analysis. Global Environmental Politics 9(4), 14-40.

Boas, L., Biermann, F., and Kanie, N. 2016. Cross-Sectoral Strategies in Global Sustainability Governance: Towards a Nexus Approach. International Environmental Agreements: Politics, Law, and Economics 16(3), 449-464.

Bradshaw, M. J. 2014. Global Energy Dilemmas: Energy Security, Globalization, and Climate Change. Cambridge: Polity Press.

Buchanan, A. and Keohane, R. 2006. The Legitimacy of Global Governance Institutions. Ethics and International Affairs 20(4), 405-437.

Bulkeley, H., Andonova, L. B., Betsill, M. M., Compagnon, D., Hale, T., Hoffmann, M. J., Newell, P., Paterson, M., Roger, C., and VanDeveer, S. D. 2014. Transnational Climate Change Governance. New York: Cambridge University Press.

Chambers, W. B. 2008. Interlinkages and the Effectiveness of Multilateral Environmental Agreements. Tokyo: United Nations University Press.

Charnovitz, S. 2003. World Trade Organization and Law Enforcement. Journal of World Trade 37(5), 817-837.

Cherp, A., Jewell, J., and Goldthau, A. 2011. Governing Global Energy: Systems, Transitions, Complexity. Global Policy 2(1), 75-88.

Clancy, J., Skutsch, M., and Batchelor, S. 2002. The Gender-Energy-Poverty Nexus: Finding the Energy to Address Gender Concerns in Development. DFID Project CNTR998521.

Dubash, N. K. and Florini, A. 2011. Mapping Global Energy Governance. Global Policy 2(1), 6-18.

Dyer, H. C. 2014. Climate Anarchy: Creative Disorder in World Politics. International Political Sociology 8(2), 182-200.

Eberlein, B., Abbott, K. W., Black, J., Meidinger, E., and Wood, S. 2014. Transnational Business Governance Interactions: Conceptualization and Framework for Analysis. Regulation \& Governance 8(1), 1-21.

Falkner, R. 2014. Global Environmental Politics and Energy: Mapping the Research Agenda. Energy Research and Social Science 1, 188-197.

Falkner, R. 2018. Climate Change, International Political Economy and Global Energy Policy. In Handbook of the International Political Economy of Energy and Natural Resources, edited by A. Goldthau, M. F. Keating, and C. Kuzemko. Cheltenham, UK: Edward Elgar Publishing.

Food and Agriculture Organization of the United Nations. 2014. The Water-Energy-Food Nexus: A New Approach in Support of Food Security and Sustainable Agriculture. Rome: Food and Agriculture Organization of the United Nations. 
Gehring, T. and Oberthur, S. 2009. The Causal Mechanisms of Interaction between International Institutions. European Journal of International Relations 15(1), 125-156.

Goldthau, A., Keating, M. F., and Kuzemko, C. 2018. Handbook of the International Political Economy of Energy and Natural Resources. Cheltenham, UK: Edward Elgar Publishing.

Goldthau, A. and Witte, J. M. 2010. Global Energy Governance: The New Rules of the Game. Washington, DC: Brookings Institution Press.

Heubaum, H. and Biermann, F. 2015. Integrating Global Energy and Climate Governance: The Changing Role of the International Energy Agency. Energy Policy 87, 229-239.

Hjerpe, M. and Nasiritousi, N. 2015. Views on Alternative Forums for Effectively Tackling Climate Change. Nature Climate Change 5(9), 864-867.

Hoff, H. 2011. Understanding the Nexus. Background Paper for the Bonn 2011 Conference: The Water, Energy and Food Security Nexus. Stockholm: Stockholm Environment Institute.

Hoffmann, M. J. 2011. Climate Governance at the Crossroads. A Global Response after Kyoto. Oxford: Oxford University Press.

IEA (International Energy Agency). 2018. World Energy Outlook 2018. Paris: IEA.

Iguchi, M., Ehara, T., Yamazaki, E., Tasaki, T., and Abe, N. 2014. Ending the Double Burden of Malnutrition: Addressing the Food and Health Nexus in the Sustainable Development Goals. POST2015/UNU-IAS Policy Brief \#8.

Jacquemont, F. and Caparrós, A. 2002. The Convention on Biological Diversity and the Climate Change Convention 10 Years after Rio: Towards a Synergy of the Two Regimes? Review of European Community and International Environmental Law 11(2), 169-180.

Jewell, J., McCollum, D., Emmerling, J., Bertram, C., Gernaat, D. E. H. J., Krey, V., Paroussos, L., Berger, L., Fragkiadakis, K., Keppo, I., Saadi, N., Tavoni, M., van Vuuren, D., Vinichenko, V. and Riahi, K. 2018. Limited Emission Reductions from Fuel Subsidy Removal Except in Energy-Exporting Regions. Nature 554, 229-233.

Jordan, A. J., Huitema, D., Hildén, M., van Asselt, H., Rayner, T. J., Schoenefeld, J. J., and Boasson, E. L. 2015. Emergence of Polycentric Climate Governance and Its Future Prospects. Nature Climate Change 5(11), 977-982.

Karlsson-Vinkhuyzen, S. I. 2010. The United Nations and Global Energy Governance: Past Challenges, Future Choices. Global Change, Peace \& Security 22(2), 175-195.

Karlsson-Vinkhuyzen, S. I. and McGee, J. 2013. Legitimacy in an Era of Fragmentation: The Case of Global Climate Governance. Global Environmental Politics 13(3), $56-78$.

Keohane, R. O. and Victor, D. G. 2011. The Regime Complex for Climate Change. Perspectives on Politics 9(1), 7-23.

Lesage, D. and Van de Graaf, T. 2016. Global Energy Governance in a Multipolar World. New York: Routledge.

Métivier, C., Postic, S., Alberola, E., and Vinnakota, M. 2018. Global Carbon Account 2018. Paris: Institute for Climate Economics, I4CE.

Moncel, R. and van Asselt, H. 2012. All Hands on Deck! Mobilizing Climate Change Action beyond the UNFCCC. Review of European Community and International Environmental Law 21(3), 163-176.

Munaretto, S. and Witmer, M. 2017. Water-Land-Energy-Food-Climate Nexus: Policies and Policy Coherence at European and International Scale. Hague: Netherlands Environmental Assessment Agency.

Nasiritousi, N. 2017. Fossil Fuel Emitters and Climate Change: Unpacking the Governance Activities of Large Oil and Gas Companies. Environmental Politics 26(4), 621-647. 
Oberthür, S. 2009. Interplay Management: Enhancing Environmental Policy Integration Among International Institutions. International Environmental Agreements: Politics, Law and Economics 9(4), 371.

Oberthür, S. and Gehring, T. (Eds.). 2006. Institutional Interaction in Global Environmental Governance: Synergy and Conflict among International and EU Policies. Cambridge, MA: MIT Press.

Oberthür, S. and Stokke, O. S. (Eds.). 2011. Managing Institutional Complexity: Regime Interplay and Global Environmental Change. Cambridge, MA: MIT Press.

Ostrom, E. 2010. Polycentric Systems for Coping with Collective Action and Global Environmental Change. Global Environmental Change 20(4), 550-557.

Pattberg, P. and Widerberg, O. 2015. Theorising Global Environmental Governance: Key Findings and Future Questions. Millennium 43(2), 684-705.

Postic, S. and Métivier, C. 2019. Global Carbon Account 2018. Paris: Institute for Climate Economics, I4CE.

Röhrkasten, S. 2018. Are We on the Cusp of a Global Renewable Energy Transition? In Oxford Handbook of Energy and Society, edited by D. J. Davidson and M. Gross. Oxford: Oxford University Press.

Sanderink, L., Widerberg, O., Kristensen, K., and Pattberg, P. 2017. Mapping the Institutional Architecture of the Climate-Energy Nexus IVM Report (R-17/04). Amsterdam: Institute for Environmental Studies, Vrije Universiteit Amsterdam.

Sovacool, B. K. 2011. An International Comparison of Four Polycentric Approaches to Climate and Energy Governance. Energy Policy 39(6), 3832-3844.

Sovacool, B. K. 2013. Energy Policy and Climate Change. In The Handbook of Global Climate and Environment Policy, edited by R. Falkner. Malden, MA: Wiley-Blackwell.

Sovacool, B. K. and Florini, A. 2012. Examining the Complications of Global Energy Governance. Journal of Energy \& Natural Resources Law 30(3), 235-263.

Sovacool, B. K. and Van de Graaf, T. 2018. Building or Stumbling Blocks? Assessing the Performance of Polycentric Energy and Climate Governance Networks. Energy Policy 118, 317-324.

Stefanski, R. 2016. Into the Mire: A Closer Look at Fossil Fuel Subsidies. SPP Research Papers 9(10).

Terton, A., Gass, P., Merrill, L., Wagner, A., and Meyer, E. 2015. Fiscal Instruments in INDCs: How Countries are Looking to Fiscal Policies to Support INDC Implementation. Geneva: International Institute for Sustainable Development.

UNEP (United Nations Environment Programme) 2018. Emissions Gap Report 2018. Nairobi: UNEP.

van Asselt, H. 2014. The Fragmentation of Global Climate Governance: Consequences and Management of Regime Interactions. Cheltenham, UK: Edward Elgar.

van Asselt, H. and Zelli, F. 2014. Connect the Dots: Managing the Fragmentation of Global Climate Governance. Environmental Economics and Policy Studies 16(2), 137-155.

van Asselt, H. and Zelli, F. 2018. Polycentric Governing by and beyond the UNFCCC. In Governance Governing Climate Change: Polycentricity in Action? edited by A. Jordan, D. Huitema, H. van Asselt and J. Foster. Cambridge: Cambridge University Press.

Van de Graaf, T. 2013. The Politics and Institutions of Global Energy Governance: Houndmills. Basingstoke, Hampshire: Palgrave Macmillan.

Van de Graaf, T. and Blondeel, M. 2018. Fossil Fuel Subsidy Reform: An International Norm Perspective. In The Politics of Fossil Fuel Subsidies and Their Reform, edited by J. Skovgaard and H. van Asselt. Cambridge: Cambridge University Press. 
Van de Graaf, T. and Colgan, J. 2016. Global Energy Governance: A Review and Research Agenda. Palgrave Communications, 2.

Van de Graaf, T. and Zelli, F. 2016. Actors, Institutions and Frames in Global Energy Politics. In Palgrave Handbook of the International Political Economy of Energy, edited by T. Van de Graaf, B. K. Sovacool, F. Kern, A. Ghosh, and M. T. Klar. London: Palgrave Macmillan.

Vogler. 2018. Energy, Climate Change, and Global Governance: The 2015 Paris Agreement in Perspective. In Oxford Handbook of Energy and Society, edited by D. J. Davidson and M. Gross. Oxford: Oxford University Press.

Widerberg, O. and Pattberg, P. 2015. International Cooperative Initiatives in Global Climate Governance: Raising the Ambition Level or Delegitimizing the UNFCCC? Global Policy 6(1), 45-56.

Widerberg, O. and Stenson, D. E. 2013. Climate Clubs and the UNFCCC. Fores Study 3, Stockholm: Fores.

Wilson, J. D. 2015. Multilateral Organizations and the Limits to International Energy Cooperation. New Political Economy 20(1), 85-106.

Young, O. R. 1996. Institutional Linkages in International Society: Polar Perspectives. Global Governance 1(2), 1-24.

Young, O. R., Chambers W. B., Kim, J. A., and ten Have, C. (Eds.). 2008. Institutional Interplay: Biosafety and Trade. Tokyo: United Nations University Press.

Zelli, F. 2011. The Fragmentation of the Global Climate Governance Architecture. WIREs: Climate Change 2(2), 255-270.

Zelli, F. and van Asselt, H. 2013. The Institutional Fragmentation of Global Environmental Governance: Causes, Consequences, and Responses. Global Environmental Politics 13(3), 1-13.

Zelli, F., Pattberg, P., Stephan, H., and van Asselt, H. 2013. Global Climate Governance and Energy Choices. In The Handbook of Global Energy Policy, edited by A. Goldthau. Chichester: Wiley-Blackwell. 
